\title{
Dietary protein requirements of abalone (Haliotis discus, Reeve 1846) depending on abalone size
}

\author{
Seong II Baek', Sung Hwoan $\mathrm{Cho}^{2, *}$ \\ ${ }^{1}$ Department of Convergence Study on the Ocean Science and Technology, Korea Maritime and Ocean University, Busan 49112, Korea \\ ${ }^{2}$ Division of Marine Bioscience, Korea Maritime and Ocean University, Busan 49112, Korea
}

\begin{abstract}
Dietary protein requirements of abalone (Haliotis discus) depending on abalone size were determined and compared. One thousand and fifty small abalone (initial weight of $2.7 \mathrm{~g}$ ) and five hundred forty large one (initial weight of $16.0 \mathrm{~g}$ ) were distributed into 15 and 18 containers in Trial 1 and 2, respectively. Five and six experimental diets containing crude protein level from 20\% to $40 \%$ and $20 \%$ to $45 \%$ with $5 \%$ increment of protein level for the small and large abalone were prepared and referred to as the CP20, CP25, CP30, CP35, CP40, and CP45 diets, respectively. The experimental diets were fed to abalone for 16 weeks in Trials 1 and 2. Specific growth rate (SGR) of the small abalone fed the CP20 diet was lower compared to that of abalone fed all other diets in Trial 1. Growth performance (weight gain and SGR) of the large abalone fed the CP30, CP35, and CP40 diets were greater than that of abalone fed the CP20, CP25, and CP45 diets in Trial 2. Dietary protein requirements were estimated to be $33.0 \%$ and $33.5 \%$ for the small and large abalone based on the $2^{\text {nd }}$ order polynomial analysis, respectively. Dietary protein requirements for the small abalone grown from $2.7 \mathrm{~g}$ to $7.4 \mathrm{~g}$ and the large one grown from $16 \mathrm{~g}$ to $21 \mathrm{~g}$ were estimated to be $33.0 \%$ and $33.5 \%$, respectively. Size differences in abalone did not affect dietary protein requirement under this experimental conditions.
\end{abstract}

Keywords: Abalone (Haliotis discus), Abalone size, Dietary protein requirement

\section{Introduction}

Annual aquaculture production of abalone has kept increasing globally because of high demand for human consumption (FAO, 2016). Since macroalgae (Undaria pinnatifida, Saccharina japonica and Eisenia bicyclis) commonly used for abalone culture in Korea and China are likely to be deficient in nutrient, such as protein (amino acid [AA]) and lipid (fatty acids) as abalone feed (Ansary et al., 2019; Jang et al., 2018; Mai et al., 1996; Myung et al., 2016; Uki et al., 1986a, 1986b ), development of artificially formulated diet is highly needed for stable aquaculture production of abalone.

Determining dietary protein requirement of abalone is very important to produce a practical diet because protein is an expensive component in formulating abalone feed. Mai et al. (1995) demonstrated that protein requirements of two species of juvenile (initial weight of 0.38 and $0.18 \mathrm{~g}$ ) abalone (H. discus hannai and $H$. tuberculata) were estimated to be $25 \%-35 \%$ and

Received: Dec 29, 2020 Revised: Feb 20, 2021 Accepted: Mar 3, 2021

*Corresponding author: Sung Hwoan Cho

Division of Marine Bioscience, Korea Maritime and Ocean University, Busan 49112, Korea

Tel: +82-51-410-4755, E-mail: chosunh@kmou.ac.kr

This is an Open Access article distributed under the terms of the Creative Commons Attribution Non-Commercial License (http://creativecommons.org/licenses/by$\mathrm{nc} / 4.0 /$ ) which permits unrestricted non-commercial use, distribution, and reproduction in any medium, provided the original work is properly cited.

Copyright $\odot 2021$ The Korean Society of Fisheries and Aquatic Science 
$35 \%$, respecitvley, for their maximum growth when one of the combined casein and gelatin-basal diets containing 0\%-50\% protein levels was fed to abalone. In the earlier study of Uki et al. (1986a), however, dietary protein requirement was reported to be $20 \%-30 \%$ for growth rate, feed conversion ratio and protein retention of juvenile (initial weight of $3.5 \mathrm{~g}$ ) abalone ( $H$. discus hannai), but the maximum growth rate was obtained in abalone fed the casein-basal diet containing $46.5 \%$ crude protein or white fish meal-basal diet containing $43.1 \%$ crude protein.

Generally speaking, the smaller or younger fish require the higher dietary protein requirements than the larger or older one (Einen \& Roem, 1997; NRC, 1993; Sweilum et al., 2005; Wilson \& Halver, 1986). Stone et al. (2013) reported that optimum dietary protein level for 1-year (initial weight of $1.8 \mathrm{~g}$ ) and 2-year old (initial weight of $22.9 \mathrm{~g}$ ) greenlip abalone (H. laevigata), known as preferred temperature condition of $18.3^{\circ} \mathrm{C}$ for growth (Gilroy \& Edwards, 1998), were $29 \%$ and $24 \%$ at $14{ }^{\circ} \mathrm{C}$, but $35 \%$ and $34 \%$ at $22{ }^{\circ} \mathrm{C}$, respectively. On the contrary, Britz \& Hecht (1997) reported that the small abalone ( $H$. midae) grown from $0.2 \mathrm{~g}$ to $1.0 \mathrm{~g}$ responded better on a $34 \%$ protein diet, but the large one grown from $7.0 \mathrm{~g}$ to $14.0 \mathrm{~g}$ responded better on a $44 \%$ protein diet when two sizes of abalone were fed with one of diets containing three $(24 \%, 34 \%$, and $44 \%)$ protein levels at $18^{\circ} \mathrm{C}$. Therefore, the optimum dietary protein requirements of abalone depending on abalone size are still controversial and need to clarify.

Dietary protein requirements of abalone (Haliotis discus, Reeve) depending on abalone size were evaluated and compared in this study.

\section{Methods}

\section{Rearing conditions of the experimental animal}

The similar size of small and large groups were bought from local abalone farms and moved to Ocean and Fisheries Research Institute (Jeju Special Self-Governing Province, Jeju, Korea). Abalone were acclimated to the experimental conditions for 2 weeks and fed with the dry Undaria at the ratio of ca. $2.0 \%-3.5 \%$ biomass daily before initiating the feeding trial.

\section{Trial 1}

One thousand and fifty small abalone [initial weight of $2.7 \mathrm{~g} \pm$ $0.01 \mathrm{~g}$ (mean $\pm \mathrm{SE}$ )] were distributed into each of $15,70 \mathrm{~L}$ plastic rectangular containers $(120 \mathrm{~cm} \times 36 \mathrm{~cm})$ (seventy abalone/ container). Five containers receiving different 5 feeds were placed into each of three 10 ton concrete raceway tanks (water volume: 2.8 ton) at a flow rate of $48.2 \mathrm{~L} / \mathrm{min} /$ raceway. The sand-filtered seawater was continuously supplied throughout the 16-week feeding trial and water temperature ranged from $14.7^{\circ} \mathrm{C}$ to $17.2^{\circ} \mathrm{C}$ (mean $\left.\pm \mathrm{SD}: 16.6 \pm 0.52^{\circ} \mathrm{C}\right)$.

Aeration was properly supplied in each raceway and photoperiod followed natural conditions. The experimental diets were daily $(1,700 \mathrm{~h})$ fed to triplicate groups of abalone at a quantity to ensure satiation (ca. $2.0 \%-3.5 \%$ of total biomass) with a small amount remaining. Dead abalone were daily eliminated and the bottoms of the containers were daily cleaned. At the end of the both 16-week feeding trial, all surviving abalone were harvested from each container and collectively weighed.

\section{Trial 2}

Five hundred forty large abalone [initial weight of $16.0 \mathrm{~g} \pm 0.04$ $\mathrm{g}$ (mean $\pm \mathrm{SE})]$ were distributed into each of $18,70 \mathrm{~L}$ plastic rectangular containers (thirty abalone/container). Six containers receiving different 6 feeds were placed into each of three 10 ton concrete raceway tanks (water volume: 2.8 ton) at a flow rate of $110 \mathrm{~L} / \mathrm{min} /$ raceway. The sand-filtered seawater was continuously supplied throughout the 16-week feeding trial and water temperature ranged from $16.8^{\circ} \mathrm{C}$ to $20.7^{\circ} \mathrm{C}$ (mean \pm SD: $18.0 \pm$ $0.71^{\circ} \mathrm{C}$ ). Other experimental conditions, except for abalone and water temperature were same as Trial 1.

The authors confirm that the ethical policies of the FAS, as noted on the journal's author guidelines, have been adhered to. No ethical approval was required for this study.

\section{Experimental diets}

Five and six experimental diets containing crude protein level from $20 \%$ to $40 \%$ and $20 \%$ to $45 \%$ with $5 \%$ increment of crude protein at the expense of dextrin for small (Trial 1) and large abalone (Trial 2) were prepared and referred to as the CP20, CP25, CP30, CP35, CP40, and CP45 diets, respectively (Table 1). Fish meal, defatted soybean meal and casein were used as protein source in the experimental diets. Dextrin and squid liver and soybean oils were used as carbohydrate and lipid sources, respectively, in the experimental diets. The experimental diets are isocaloric at $14.8 \mathrm{~kJ} / \mathrm{g}$ diet.

All ingredients were mechanically mixed well after $22 \%$ sodium alginate was added, and then water was added at a ratio of 1:1. A paste was made from each of the diets by using an electronic mixer (Samwoo Industry, Daegu, Korea) and shaped into $0.15 \mathrm{~cm}$ thick sheets, which were then cut by hand into $1 \mathrm{~cm}^{2}$ 
Table 1. Ingredient and chemical composition of the experimental diets (\%, DM basis)

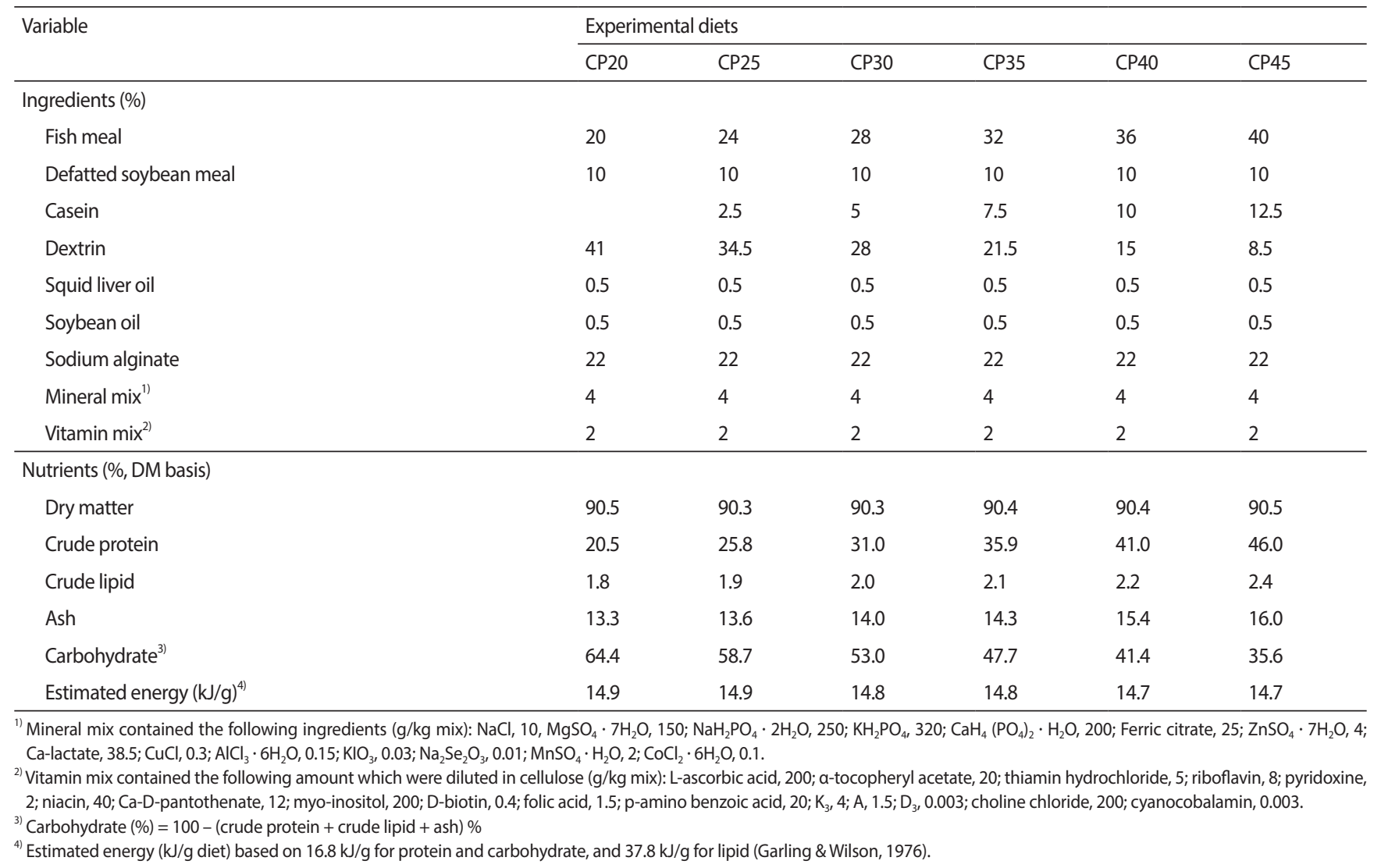

flakes. The flakes were then dipped into an aqueous solution of $5 \% \mathrm{CaCl}_{2}$ for 1 minute and then dried in a convection oven at $35^{\circ} \mathrm{C}$ for 2 days. They were stored frozen at $-20^{\circ} \mathrm{C}$ until use.

\section{Evaluation of growth performance of abalone}

Weight gain (g/abalone) of abalone was calculated as follows: Final weight of abalone - Initial weight of abalone. Specific growth rate (SGR, \%/day) was calculated using the formula of Britz (1996b): SGR = [(Ln (final weight of abalone) - Ln (Initial weight of abalone) / Days of feeding] $\times 100$. Weight gain used for regression analysis was calculated as follows: weight gain (\%) of abalone $=[($ Final weight of abalone - Initial weight of abalone) / Initial weight of abalone)] $\times 100$.

\section{Chemical analysis of the experimental diets and carcass of abalone}

At the end of 16-week feeding trial, 20 abalone from each container in the small abalone study (Trial 1) were sampled and frozen at $-20{ }^{\circ} \mathrm{C}$ for the chemical analysis. The experimental diets and all separated carcass of abalone from each container were homogenized for the chemical analysis based on the standard method of AOAC (1990); moisture content determined by drying at $105^{\circ} \mathrm{C}$ for $24 \mathrm{~h}$, crude protein content determined by Kjeldahl method (Buchi B-324/435/412; Auto Kjeldahl System, Flawil, Switzerland), crude lipid content determined by an ether-extraction method and ash determined by using a muffle furnace at $550^{\circ} \mathrm{C}$ for $4 \mathrm{~h}$.

The AA composition of the experimental diets (Trial 2) was determined by using a high speed AA analyzer (Hitachi L-8800, Hitachi, Tokyo, Japan) after which the samples were hydrolyzed in $6 \mathrm{~N} \mathrm{HCl}$ for $24 \mathrm{~h}$ at $110^{\circ} \mathrm{C}$.

\section{Statistical analysis}

One-way ANOVA and Duncan 's multiple range test (Duncan, 1955) were used to determine the significance of the differences among the means of treatments by using SAS version 9.3 program (SAS Institute, Cary, NC, USA). Regression analysis was applied to evaluate dietary protein requirements of the small and large sizes of abalone (Lovell, 1989). 


\section{Results}

AA profiles of the experimental diets (Trial 2) are presented in Table 2. All essential and non-essential AA of the experimental diets were proportionally increased with dietary protein levels. Leucine and glutamic acid were the richest essential and non-essential AA in the experimental diets, respectively.

Survival and weight gain of the small abalone was not significantly $(p>0.05)$ influenced by dietary protein level (Table 3). However, SGR of the small abalone fed the CP20 diet was statistically $(p<0.05)$ lower than that of abalone fed all other diets. Dietary protein requirement for the small abalone was estimated to be approximately $33.0 \%$ based on the $2^{\text {nd }}$ polynomial analysis (weight gain vs dietary protein level) (Fig. 1).

Survival of the large abalone was not significantly $(p>0.05)$ influenced by dietary protein level (Table 4 ). However, weight gain and SGR of the large abalone fed the CP30, CP35, and CP40 diets were statistically $(p<0.05)$ greater than those of abalone fed the CP20, CP25, and CP45 diets. The greatest weight gain and SGR were obtained in large abalone fed the CP30 diet, but lowest ones for the CP20 diet. Dietary protein requirement for the large abalone was estimated to be approximately $33.5 \%$ based on the $2^{\text {nd }}$ polynomial analysis (weight gain vs dietary protein level) (Fig. 2).

However, moisture, crude lipid and ash content of the carcass of the small abalone was not statistically $(p>0.05)$ affected by dietary protein level in Trial 1 (Table 5 ). However, crude protein content of the carcass of the small abalone increased with dietary protein level.

\section{Discussion}

The essential and non-essential AA content in the experimental diets increased with dietary protein level. Many researchers (Bautista-Teruel et al., 2003; Cho, 2010; Cho et al., 2008; Shipton \& Britz, 2001) reported that essential AA, such as lysine, methionine and histidine are limiting factors to determine substitutability of the alternative animal and/or plant protein sources for fish meal in abalone feed or compare formulated diets with macroalgae for growth of abalone. Mai et al. (1994) also

Table 2. Amino acid profiles of the experimental diets in Trial 2 ( $\%$ of the diet)

\begin{tabular}{|c|c|c|c|c|c|c|}
\hline \multirow[t]{2}{*}{ Variable } & \multicolumn{6}{|c|}{ Experimental diets } \\
\hline & CP20 & $\mathrm{CP} 25$ & CP30 & CP35 & CP40 & CP45 \\
\hline \multicolumn{7}{|c|}{ Essential amino acids (EAA) } \\
\hline Arginine & 1.09 & 1.25 & 1.52 & 1.73 & 1.94 & 2.12 \\
\hline Histidine & 0.58 & 0.71 & 0.89 & 1.01 & 1.15 & 1.28 \\
\hline Isoleucine & 0.84 & 1.06 & 1.35 & 1.54 & 1.79 & 1.98 \\
\hline Leucine & 1.46 & 1.86 & 2.39 & 2.73 & 3.17 & 3.53 \\
\hline Lysine & 1.41 & 1.76 & 2.23 & 2.57 & 2.95 & 3.29 \\
\hline Methionine & 0.41 & 0.53 & 0.68 & 0.80 & 0.88 & 0.95 \\
\hline Phenylalanine & 0.83 & 1.04 & 1.31 & 1.48 & 1.69 & 1.90 \\
\hline Threonine & 0.85 & 1.02 & 1.29 & 1.47 & 1.68 & 1.83 \\
\hline Valine & 0.99 & 1.23 & 1.58 & 1.81 & 2.10 & 2.32 \\
\hline$\Sigma$ EAA & 8.46 & 10.46 & 13.24 & 15.14 & 17.35 & 19.20 \\
\hline \multicolumn{7}{|c|}{ Non-essential amino acids (NAA) } \\
\hline Alanine & 1.12 & 1.31 & 1.59 & 1.79 & 2.02 & 2.20 \\
\hline Aspartic acid & 1.91 & 2.24 & 2.76 & 3.09 & 3.50 & 3.81 \\
\hline Cystine & 0.21 & 0.23 & 0.28 & 0.31 & 0.34 & 0.36 \\
\hline Glutamic acid & 2.73 & 3.48 & 4.46 & 5.16 & 6.03 & 6.67 \\
\hline Glycine & 1.03 & 1.20 & 1.43 & 1.60 & 1.80 & 1.97 \\
\hline Proline & 0.82 & 1.15 & 1.56 & 1.86 & 2.25 & 2.56 \\
\hline Serine & 0.82 & 1.00 & 1.28 & 1.47 & 1.71 & 1.87 \\
\hline Tyrosine & 0.53 & 0.65 & 0.84 & 1.01 & 1.30 & 1.35 \\
\hline$\sum \mathrm{NAA}$ & 9.17 & 11.26 & 14.20 & 16.29 & 18.95 & 20.79 \\
\hline
\end{tabular}


Table 3. Survival (\%), weight gain (g/abalone) and specific growth rate (SGR, \%/day) of the small abalone fed the experimental diets for 16 weeks in Trial 1

\begin{tabular}{|c|c|c|c|c|c|}
\hline Experimental diets & Initial weight (g/abalone) & Final weight (g/abalone) & Survival (\%) & Weight gain"1) (g/abalone) & $\mathrm{SGR}^{2)}(\% /$ day) \\
\hline CP20 & $2.7 \pm 0.02$ & $6.3 \pm 0.21^{a}$ & $82.4 \pm 5.04^{\mathrm{a}}$ & $3.6 \pm 0.19^{a}$ & $0.74 \pm 0.023 b$ \\
\hline $\mathrm{CP} 25$ & $2.7 \pm 0.00$ & $7.2 \pm 0.43^{\mathrm{a}}$ & $85.2 \pm 4.54^{\mathrm{a}}$ & $4.6 \pm 0.43^{\mathrm{a}}$ & $0.86 \pm 0.053^{\mathrm{a}}$ \\
\hline $\mathrm{CP} 30$ & $2.7 \pm 0.01$ & $7.4 \pm 0.36^{\mathrm{a}}$ & $82.4 \pm 3.33^{\mathrm{a}}$ & $4.7 \pm 0.37^{\mathrm{a}}$ & $0.88 \pm 0.045^{a}$ \\
\hline CP35 & $2.7 \pm 0.00$ & $7.2 \pm 0.26^{\mathrm{a}}$ & $89.0 \pm 3.43^{\mathrm{a}}$ & $4.5 \pm 0.24^{\mathrm{a}}$ & $0.84 \pm 0.026^{\mathrm{a}}$ \\
\hline $\mathrm{CP} 40$ & $2.7 \pm 0.01$ & $7.3 \pm 0.22^{\mathrm{a}}$ & $90.5 \pm 2.65^{\mathrm{a}}$ & $4.6 \pm 0.22^{\mathrm{a}}$ & $0.86 \pm 0.025^{\mathrm{a}}$ \\
\hline
\end{tabular}

Values (means of triplicate $\pm \mathrm{SE}$ ) in the same column sharing a common superscript are not statistically different $(p>0.05)$.

${ }^{1)}$ Weight gain (g/abalone) $=$ Final weight of abalone - Initial weight of abalone.

${ }^{2)}$ Specific growth rate $(\mathrm{SGR}, \% /$ day $)=$ [(Ln (Final weight of abalone) - Ln (Initial weight of abalone) / Days of feeding $] \times 100$.

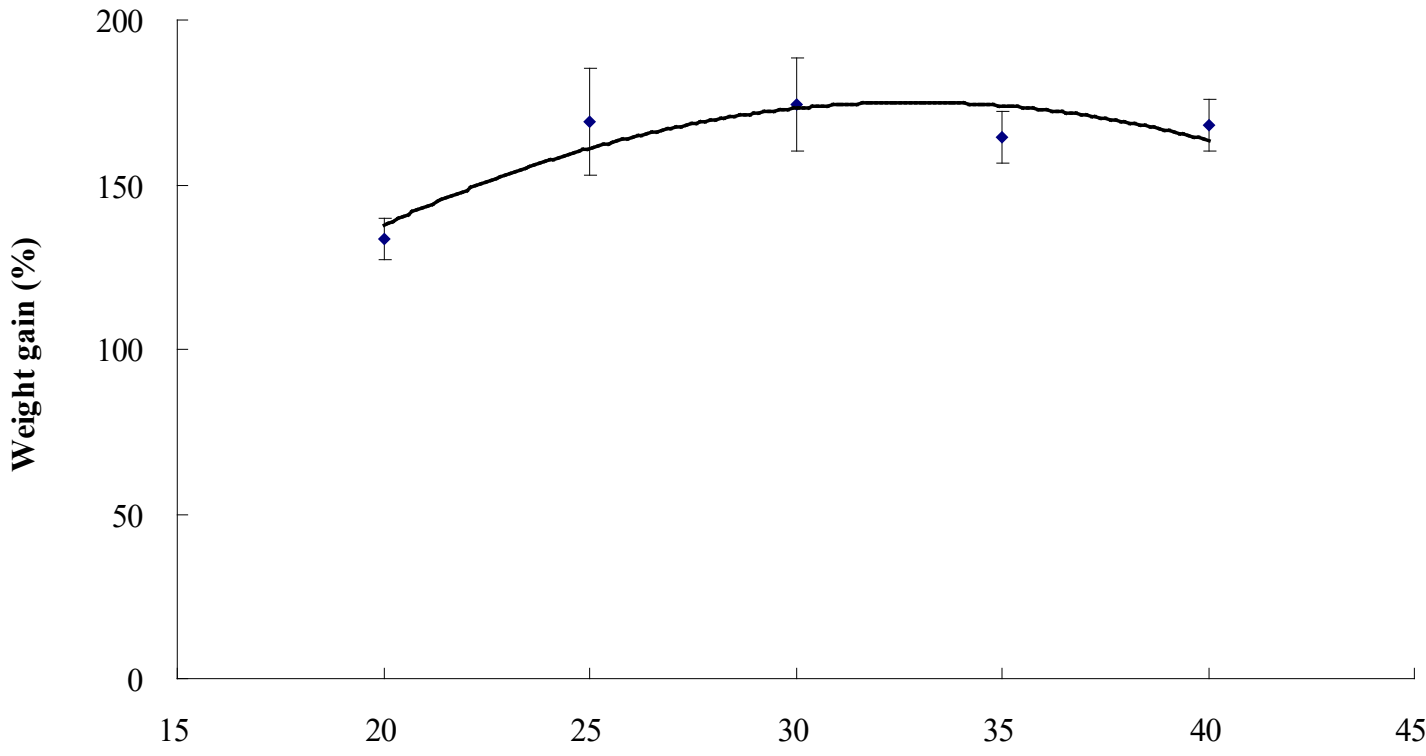

Protein level (\%)

Fig. 1. Second order polynomial regression analysis between weight gain (\%) of the small abalone and dietary protein level in Trial 1 (means of triplicate $\pm S E) .\left(Y=-0.23 X^{2}+14.83 X-68.77, R^{2}=0.81, p<0.001\right)\left(Y_{\max }\right.$ value when $X$ value $\left.=33.0 \%\right)$.

Table 4. Survival (\%), weight gain (g/abalone) and specific growth rate (SGR) of the large abalone fed the experimental diets for 16 weeks in Trial 2

\begin{tabular}{|c|c|c|c|c|c|}
\hline Experimental diets & Initial weight (g/abalone) & Final weight (g/abalone) & Survival (\%) & Weight gain ${ }^{1)}$ (g/abalone) & $\mathrm{SGR}^{2)}(\% /$ day $)$ \\
\hline $\mathrm{CP} 20$ & $16.0 \pm 0.04$ & $19.7 \pm 0.03^{c}$ & $94.4 \pm 2.22^{\mathrm{a}}$ & $3.6 \pm 0.06^{c}$ & $0.18 \pm 0.003^{c}$ \\
\hline CP25 & $16.0 \pm 0.04$ & $19.7 \pm 0.03^{c}$ & $93.3 \pm 3.33^{\mathrm{a}}$ & $3.7 \pm 0.01^{c}$ & $0.19 \pm 0.001^{c}$ \\
\hline $\mathrm{CP} 30$ & $16.1 \pm 0.02$ & $20.9 \pm 0.11^{\mathrm{a}}$ & $91.1 \pm 1.11^{\mathrm{a}}$ & $4.8 \pm 0.09^{\mathrm{a}}$ & $0.23 \pm 0.004^{\mathrm{a}}$ \\
\hline CP35 & $16.0 \pm 0.02$ & $20.3 \pm 0.16^{b}$ & $91.1 \pm 1.11^{\mathrm{a}}$ & $4.4 \pm 0.17^{b}$ & $0.22 \pm 0.007^{\mathrm{ab}}$ \\
\hline $\mathrm{CP} 40$ & $16.1 \pm 0.04$ & $20.3 \pm 0.80^{b}$ & $93.3 \pm 0.00^{\mathrm{a}}$ & $4.2 \pm 0.10^{b}$ & $0.21 \pm 0.005^{b}$ \\
\hline $\mathrm{CP} 45$ & $16.0 \pm 0.09$ & $19.8 \pm 0.11^{c}$ & $93.3 \pm 3.33^{\mathrm{a}}$ & $3.8 \pm 0.16^{c}$ & $0.19 \pm 0.008^{c}$ \\
\hline
\end{tabular}

Values (means of triplicate $\pm \mathrm{SE}$ ) in the same column sharing a common superscript are not statistically different $(p>0.05)$.

${ }^{11)}$ Weight gain (g/abalone) $=$ Final weight of abalone - Initial weight of abalone.

${ }^{2)}$ Specific growth rate (SGR, \%/day) $=$ [(Ln (Final weight of abalone) - Ln (Initial weight of abalone) / Days of feeding $] \times 100$. 


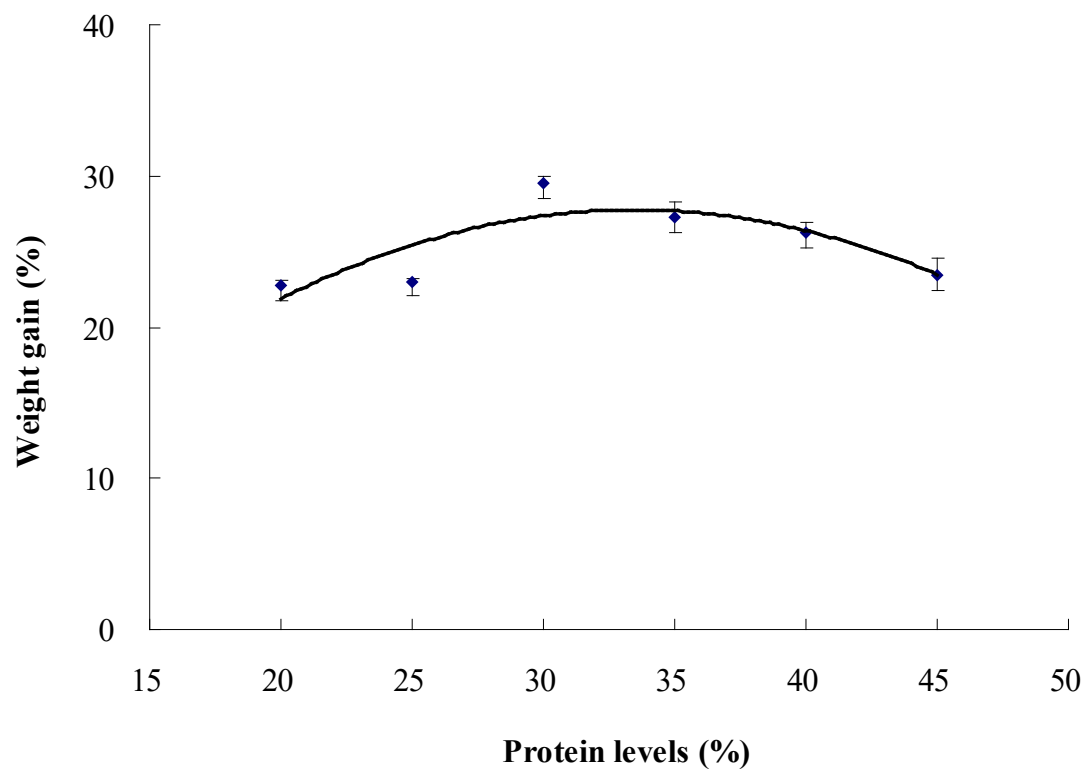

Fig. 2. Second order polynomial regression analysis between weight gain (\%) of the large abalone and dietary protein level in Trial 2 (Means of triplicate $\pm S E)$. $\left(Y=-0.03 X^{2}+2.16 X-8.44, R^{2}=0.70, p<0.001\right)\left(Y_{\max }\right.$ value when $X$ value $\left.=33.5 \%\right)$.

Table 5. Chemical composition (\%, wet weight) of the carcass of the small abalone fed the experimental diets for 16 weeks in Trial 1

\begin{tabular}{lllll}
\hline Experimental diets & Moisture & Crude protein & Crude lipid & Ash \\
\hline CP20 & $77.2 \pm 0.07^{\mathrm{a}}$ & $16.4 \pm 0.02^{\mathrm{a}}$ & $1.2 \pm 0.01^{\mathrm{a}}$ & $2.2 \pm 0.02^{\mathrm{a}}$ \\
CP25 & $77.2 \pm 0.04^{\mathrm{a}}$ & $17.0 \pm 0.04^{\mathrm{b}}$ & $1.2 \pm 0.01^{\mathrm{a}}$ & $2.2 \pm 0.03^{\mathrm{a}}$ \\
CP30 & $77.3 \pm 0.04^{\mathrm{a}}$ & $17.8 \pm 0.06^{\mathrm{c}}$ & $1.2 \pm 0.03^{\mathrm{a}}$ & $2.3 \pm 0.02^{\mathrm{a}}$ \\
CP35 & $77.3 \pm 0.03^{\mathrm{a}}$ & $18.3 \pm 0.05^{\mathrm{d}}$ & $1.2 \pm 0.00^{\mathrm{a}}$ & $2.2 \pm 0.04^{\mathrm{a}}$ \\
CP40 & $77.2 \pm 0.05^{\mathrm{a}}$ & $19.4 \pm 0.07^{\mathrm{e}}$ & $1.2 \pm 0.02^{\mathrm{a}}$ & $2.2 \pm 0.05^{\mathrm{a}}$ \\
\hline
\end{tabular}

Values (means of triplicate $\pm \mathrm{SE}$ ) in the same column sharing a common superscript are not statistically different $(p>0.05)$.

compared AA profiles of 6 species of macroalgae (Laminaria saccharina, L. digitata, Ulva lactuca, Chondrus crispus, Palmaria palmate and Alaria esculenta) commonly used as natural feeds for 2 species abalone ( $H$. tuberculata and $H$. discus hannai) and concluded that arginine could be limiting factor in all macroalgae tested in abalone, but methionine, threonine or histidine might be also another limiting factor in some macroalgae.

The greatest weight gain and SGR were obtained in abalone fed the CP30 diet regardless abalone size in this study. Since temperature condition is not quite different for both small (mean temperature of $16.6^{\circ} \mathrm{C}$ ) and large abalone (mean temperature of $18.0^{\circ} \mathrm{C}$ ) in this study, it did not influence either growth performance of abalone or availability dietary optimum protein level. No distinctive difference in dietary protein requirements for the small and large abalone in this study is in consistent with Stone et al. (2013)'s study showing that the optimal dietary protein levels for 1- and 2-year old greenlip abalone (H. laevigata) were $35 \%$ and $34 \%$ at $22^{\circ} \mathrm{C}$, respectively when abalone were fed with one of four protein levels $(24 \%, 27 \%, 31 \%$, and $37 \%)$ of diets containing solvent-extracted soybean meal, lupins and salmon fish meal as protein source at $14^{\circ} \mathrm{C}, 18^{\circ} \mathrm{C}$, and $22^{\circ} \mathrm{C}$ for 12 weeks. However, there are also some conflicting studies showing that optimal protein level for 1-year old abalone was 29\%, on the other hand, $24 \%$ for 2 -year old one at $14^{\circ} \mathrm{C}$ (Stone et al., 2013) or that large (initial weight of $7 \mathrm{~g}$ ) abalone ( $H$. midae) grew better on a $44 \%$ protein diet, on the other hand, small (initial weight of $0.2 \mathrm{~g}$ ) one grew better on a $34 \%$ protein diet (Britz and Hecht, 1997). Generally speaking, the smaller or younger fish require the higher dietary protein levels than the larger or older one (Einen \& Roem, 1997; NRC, 1993; Sweilum et al., 
2005; Wilson \& Halver, 1986).

Mai et al. (1995) reported dietary protein level of 35\% for maximum growth of abalone and $25 \%-35 \%$ for requirements when the mixture of casein and gelatin-basal diets containing various protein levels $(0 \%-50 \%)$ were fed to two species of juvenile abalone ( $H$. discus hannai) grown from $0.38 \mathrm{~g}$ to $0.97 \mathrm{~g}$ and (H. tuberculata) grown from $0.18 \mathrm{~g}$ to $0.55 \mathrm{~g}$, respectively, at $13{ }^{\circ} \mathrm{C}-15^{\circ} \mathrm{C}$. Uki et al. (1986a) also demonstrated that dietary protein requirement was $20 \%-30 \%$ based on growth rate, feed conversion ratio and protein retention when the caseinand white fish meal-basal diet was fed to juvenile abalone $(H$. discus hannai) grown from $3.5 \mathrm{~g}$ to $4.8 \mathrm{~g}$, however, the greatest growth rate was achieved in abalone fed the casein-basal diet containing $46.5 \%$ crude protein or white fish meal-basal diet containing $43.1 \%$ crude protein at $19.7^{\circ} \mathrm{C}$. Similarly, Coote et al. (2000) showed that the greatest SGR was obtained in abalone $(H$. laevigata) fed a $29.9 \%$ protein diet when abalone were fed with one of diets containing protein levels of $12.0 \%$ to $46.1 \%$ and reported dietary protein requirement of $27 \%$. Sales et al. (2003) reported that dietary protein requirement was estimated to be $25.5 \%$ based on broken-line analysis for weight gain of juvenile South African abalone (H. midae), but the greatest weight gain was achieved in abalone fed a $39.4 \%$ protein diet when diets containing various protein levels $(5.5 \%, 13.4 \%, 21.8 \%, 28.6 \%$, $39.4 \%$, and $47.9 \%$ ) were fed to abalone for 95 days.

The smaller abalone achieved the higher SGR than larger one in this study, being consistent with other studies (Britz \& Hecht, 1997; Stone et al., 2013) showing that the smaller abalone grew faster than the larger one at the same temperature condition.

Crude protein content of the carcass of the small abalone was well reflected from dietary protein content. Similarly, proximate of the carcass of abalone was well reflected from dietary nutrient composition (Garcia-Esquivel \& Felbeck, 2009; Jang et al., 2018; Myung et al., 2016; Sales et al., 2003; Thongrod et al., 2003; Uki et al., 1986a).

\section{Conclusion}

Dietary protein requirements for the small (initial weight of 2.7 $\mathrm{g}$ ) and large (initial weight of $16.0 \mathrm{~g}$ ) abalone were estimated to be $33.0 \%$ and $33.5 \%$, respectively. Size differences in abalone did not affect dietary protein requirement under this experimental conditions.

\section{Competing interests}

No potential conflict of interest relevant to this article was reported.

\section{Funding sources}

This work was supported by the National Research Foundation of Korea (NRF) grant funded by the Korean government (No. 2020R1A2C1009903). This study was also partially supported by Basic Science Research Program through the National Research Foundation of Korea (NRF) funded by the Ministry of Science, ICT and Future planning (2017R1A2B4009773).

\section{Acknowledgements}

Not applicable.

\section{Availability of data and materials}

Upon reasonable request, the datasets of this study can be available from the corresponding author.

\section{Ethics approval and consent to participate}

Not applicable.

\section{ORCID}

Sung Hwoan Cho https://orcid.org/0000-0002-6973-5449

\section{References}

Ansary MWR, Baek SI, Jeong HS, Lee KW, Cho SH, Kim HS, et al. Substitution effect of the combined fouling macroalgae Ulva australis and Sargassum horneri for Undaria pinnatifida in formulated diets on growth and body composition of juvenile abalone (Haliotis discus, Reeve 1846) subjected to air exposure stressor. J Appl Phycol. 2019:31:3245-54.

AOAC [Association of Official Analytical Chemists]. Official methods of analysis. 15th ed. Arlington, VA: AOAC; 1990.

Bansemer MS, Qin JG, Harris JO, Howarth GS, Stone DAJ. Nutritional requirements and use of macroalgae as ingredients in abalone feed. Rev Aquac. 2016;8:121-35.

Bautista-Teruel MN, Fermin AC, Koshio SS. Diet development and evaluation for juvenile abalone, Haliotis asinina: animal and plant protein sources. Aquaculture. 2003;219:645-53.

Britz PJ. Effect of dietary protein level on growth performance of South African abalone, Haliotis midae, fed fishmeal-based semi-purified diets. Aquaculture. 1996a;140:55-61.

Britz PJ. The suitability of selected protein sources for inclusion 
in formulated diets for the South African abalone, Haliotis midae. Aquaculture. 1996b;140:63-73.

Britz PJ, Hecht T. Effect of dietary protein and energy level on growth and body composition of South African abalone, Haliotis midae. Aquaculture. 1997;156:195-210.

Cho SH. Effect of fishmeal substitution with various animal and/or plant protein sources in the diet of the abalone Haliotis discus hannai Ino. Aquac Res. 2010;41:e587-93.

Cho SH, Park J, Kim C, Yoo JH. Effect of casein substitution with fishmeal, soybean meal and crustacean meal in the diet of the abalone Haliotis discus hannai Ino. Aquac Nutr. 2008;14:61-6.

Coote TA, Hone PW, Van Barneveld RJ, Maguire GB. Optimal protein level in a semipurified diet for juvenile greenlip abalone Haliotis laevigata. Aquac Nutr. 2000;6:213-20.

Duncan DB. Multiple range and multiple F tests. Biometrics. 1955;11:1-42.

Dunstan GA. A simple model for the determination of the relative utilization efficiency of protein by blacklip abalone (Haliotis rubra Leach). Aquac Nutr. 2010;16:1-12.

Einen O, Roem AJ. Dietary protein/energy ratios for Atlantic salmon in relation to fish size: growth, feed utilization and slaughter quality. Aquac Nutr. 1997;3:115-26.

FAO [Food and Agriculture Organization of the United Nations]. The state of world fisheries and aquaculture. Rome: FAO; 2016.

Garling DL, Wilson RP. Optimum dietary protein to energy ratio for channel catfish fingerlings, Ictalurus punctatus. J Nutr. 1976;106:1368-75.

Gilroy A, Edwards SJ. Optimum temperature for growth of Australian abalone: preferred temperature and critical thermal maximum for blacklip abalone, Haliotis rubra (Leach), and greenlip abalone, Haliotis laevigata (Leach). Aquac Res. 1998;29:481-5.

Garcia-Esquivel Z, Felbeck H. Comparative performance of juvenile red abalone, Haliotis rufescens, reared in laboratory with fresh kelp and balanced diets. Aquac Nutr. 2009;15:209-17.

Gómez-Montes L, García-Esquivel Z, D’Abramo LR, Shimada A, Vásquez-Peláez C, Viana MT. Effect of dietary protein: energy ratio in intake, growth and metabolism of juvenile green abalone Haliotis fulgens. Aquaculture. 2003;220:769-80.

Jang B, Kim PY, Kim HS, Lee KW, Kim HJ, Choi DG, et al. Substitution effect of sea tangle (ST) (Laminaria japonica) with tunic of sea squirt (SS) (Halocynthia roretzi) in diet on growth and carcass composition of juvenile abalone (Haliotis discus, Reeve 1846). Aquac Nutr. 2018;24:586-93.

Lovell T. Nutrition and feeding of fish. New York, NY: Van Nostrand Reinhold; 1989.

Mai K, Mercer JP, Donlon J. Comparative studies on the nutrition of two species of abalone, Haliotis tuberculata L. and Haliotis discus hannai Ino: II. amino acid composition of abalone and six species of macroalgae with an assessment of their nutritional value. Aquaculture. 1994;128:115-30.

Mai K, Mercer JP, Donlon J. Comparative studies on the nutrition of two species of abalone, Haliotis tuberculata L. and Haliotis discus hannai Ino. IV. optimum dietary protein level for growth. Aquaculture. 1995;136:165-80.

Mai K, Mercer JP, Donlon J. Comparative studies on the nutrition of two species of abalone, Haliotis tuberculata L. and Haliotis discus hannai Ino. V. the role of polyunsaturated fatty acids of macroalgae in abalone nutrition. Aquaculture. 1996;139:77-89.

Myung SH, Jung WG, Kim HS, Kim YE, Cho SH, Jwa MS, et al. Effects of dietary substitution of fishmeal with the combined dry microalgae, Nannochloropsis oceanica (NO) biomass residue and casein on growth and body composition of juvenile abalone (Haliotis discus). Aquac Res. 2016;47:341-8.

National Research Council [NRC]. Nutrients requirements of fish. Washington, DC: National Academy Press; 1993.

Sales J, Truter PJ, Britz PJ. Optimum dietary crude protein level for growth in South African abalone (Haliotis midae L.). Aquac Nutr. 2003;9:85-9.

Shipton TA, Britz PJ. The partial and total replacement of fishmeal with selected plant protein sources in diets for the South African abalone, Haliotis midae L. J Shellfish Res. 2001;20:637-46.

Stone DAJ, Harris JO, Wang H, Mercer GJ, Schaefer EN, Bansemer MS. Dietary protein level and water temperature interactions for greenlip abalone Haliotis laevigata. J Shellfish Res. 2013;32:119-30.

Sweilum MA, Abdella MM, El-Din SAS. Effect of dietary protein-energy levels and fish initial sizes on growth rate, development and production of Nile tilapia, Oreochromis niloticus L. Aquac Res. 2005;36:1414-21.

Thongrod S, Tamtin M, Chairat C, Boonyaratpalin M. Lipid to carbohydrate ratio in donkey's ear abalone (Haliotis asinina, Linne) diets. Aquaculture. 2003;225:165-74.

Uki N, Kemuyama A, Watanabe T. Optimum protein level in 
diets for abalone. Bull Jpn Soc Sci Fish. 1986a;52:1005-12.

Uki N, Sugiura M, Watanabe T. Requirement of essential fatty acids in the abalone Haliotis discus hannai. Bull Jpn Soc Sci Fish. 1986b;52:1013-23.

Wilson RP, Halver JE. Protein and amino acid requirements of fishes. Annu Rev Nutr. 1986;6:225-44. 